\title{
Financial Reporting and Shareholders' Crave for Investment in Nigerian Listed Companies: The Earnings Management Question
}

\author{
Uwem E. Uwah and Joseph O. Udoayang
}

\begin{abstract}
This study examined the extent to which earnings management could be a factor in the higher value of stock in the Nigerian capital market, thereby being an inducement to invest in companies listed in the Nigerian Stock Exchange. The contemporary viewpoint of financial consultants, firm of auditors and academicians about the subject matter was sought. Interviews were granted, in conjunction with secondary data from the Security and Exchange Commission and the Nigerian Stock Exchange. A comprehensive research design which was garnished by the use of content analysis of relevant literature and theories was adopted. The findings of previous empirical studies were corroborated in the analysis from discussions with accounting professionals in the academia and audit firms. It was concluded that most investments in quoted companies are made as a result of earnings management mechanisms inherent in financial reports. It was recommended that the Financial Reporting Council of Nigeria and every stakeholder should act to ensure that corporate governance practice is actually achieved for sound financial reporting practice.

Index Terms-Earnings management; Financial reporting;
\end{abstract} Investment; Shareholders.

\section{INTRODUCTION}

In accounting, the term 'earnings management' is a manifestation of insincerity on the part of management to give false financial report about an entity in order to enjoy some form of private benefits [8]. According to [25] stakeholders would be deceived through the published financial statements, and potential as well as existing shareholders are misinformed, thereby investing in the companies they would not have invested.

Professional accountants in Nigeria, and the world over have realized the negative disposition of this practice and how it could weaken the financial reporting process and its credibility [13].

Published on May 22, 2020

Uwem E. Uwah, Department of Accounting, Faculty of Management

Sciences, Akwa Ibom State University, Nigeria.

(corresponding e-mail: uwemuwah@aksu.edu.ng)

Joseph O. Udoayang, Department of Accounting, Faculty of

Management Sciences, University of Calabar, Nigeria.

(e-mail: josephudoayang@yahoo.com)
Howbeit, earnings management may be difficult to detect by individual investors owing to the complexity of accounting rules. Companies that have weak corporate governance and could not contain large accruals in its accounting policy would resort to manipulating the figures which could lure the investors into buying stock or bonds in the company [24].

The security and Exchange Commission, the world over have criticized the use of earnings management by companies as the consequence on financial reporting is phenomenally adverse. This begs the question of how efficient the regulators of accounting standards, in their oversight function and how the accounting standards issued can stand the test of time. [20] assert that the adoption and implementation of standards approved by the International Federation of Accountants (IFAC), such as the International Public Sector Accounting standards (IPSAS) and the International Financial Reporting Standards (IFRS) with the built-in provisions to fight earnings management in the private sector is a welcome development.

[12] maintained that earnings management distort the precepts and practice of financial reporting because management uses this method of accounting to present the financial statements the way they desire and not the true position of the organisation's affairs. To the investors, Sullivan and [1] opined that they have to make investment decisions that would give them a pay off to increase their earnings. [6] remarked that investors take investment risks with the hope to gain in the future. In Nigeria today, both the institutional and private investors actively redirect their resources and make investments to create benefits in the future, but unfortunately fall into the trap set by 'greedy' or incompetent management through the earnings management mechanism.

The questions posed by earnings management problem are the sufficiency or otherwise of the provisions of the financial standards and the generally accepted accounting principles (GAAP). The next question is the ethical question on the part of the regulators and the professional accountants - auditors and academia and indeed what the government brings to the table through the operations of the antigraft agencies, such as the Economic and Financial Crimes Commission (EFCC) in Nigeria.

The gap to be filled in this study is the need to intensify investor education, with regards to business valuation. Though [22] citing [2] maintained that Nigerian shareholders do not rely much on information from financial statements before their decision to invest in companies. According to [22] the reliance of most Nigerian 
investors is on the frequency of dividends payment by companies and the attendant market value in the stock market. [14] opined that financial reports play material effect on investors' decision to sink or swim with quoted companies in the stock exchange. This study therefore examined the extent to which the afore-mentioned assertions are true and the extent to which earnings management could be a factor in the higher value of stock in the Nigerian capital market.

\section{LITERATURE REVIEW}

To adequately review the related literature in this study, this section is segmented into conceptual framework, theoretical framework and empirical framework.

\section{A. Conceptual Framework}

[25] opined that the major factors affecting residual growth and earnings are inventory valuation and depreciation methods among others. With these, management may decide to manage earnings to favour the company. This would however be in the short run. [4] in his study revealed that debt covenants are violated by management in order to remove liabilities from the statement of financial position (balance sheet) and post higher profit than other companies even in the same sector and economy. This exercise put the company in question as a performer, albeit fictitiously. Investment in certain financial derivations are carried out by some companies to showcase excellent traditional investment in debt and equity securities which turn out to be false earnings. Such derivations may be in the area of options to purchase or sell stock or in some cases, commodities warrant to purchase stock, commodity feature and forwards as well as other swap agreements [17].

Earnings growth and residual earnings can be manipulated through accounting methods, but real economic value is achieved by real factors which the investment analyst can distinguish between the real value added and the manipulation from accounting records [15]. In the earliest study on earnings management as done by [10] he concluded that operating cashflows and total accruals are valued differently, and these values are relevant as far as the market is concerned.

The conceptual review of this study on the effect of earnings management on financial reporting and the incidence on investors using the capital market indicates that:

1) The market appears to retreat to the value relevance (disclosure of detailed cash flow and accrual data) and

2) Differential valuation (where cash flows are more highly valued than accruals).

In either situation, [3] posits that management puts the bait in the market, depending on what they want the investors to see. This is earnings management when the real value of the company is not reflected in the market. It was earlier found out by other studies that segmenting earnings into cash flow and accrual components is useful in the identification of securities that have the tendency to under or over-perform in the future. This is averse to the efficient market hypothesis concept [9].

\section{PROFITABILITY CONCEPT}

[8] saw profitability as an attribute of earnings management with the attendant effect on investors' psyche and they came up with the conclusion that everything will boil down to understanding which asset or liabilities have been misreported in the financial statements to mislead the current and prospective shareholders.

Every investor would want to be associated with a profitoriented enterprise and profitability is a relative measure which is seen when alternative courses of action are available, and a more profitable alternative is accepted when decision is to be taken [21]. Citing [21], [3] asserts that the accounting concept of profit portrays efficacy of sales transactions by companies in a period which brings new assets into the business in exchange for those within the business enterprises. This surmises that there would be profit if the assets are in excess and the society will evaluate these assets in the market through marketing bargains.

To be seen as effective managers of resources, management may resort to earnings management where high fictitious profits are posted. Earnings management may come in various forms, with tax avoidance being used as enhancer. If management engages in excessive tax avoidance activities, shareholders wealth will increase but this could lead to a reputational damage and payment of penalties if discovered by the tax authorities which would culminate into cash flow reduction and a twist on the shareholders' wealth [18]; [19]; [11].

Other attributes of earnings management as revealed by [3] are:

1) Incorrect recording of transactions such as making a long-term contract look as though all revenues were earned up-front. This has the tendency of swelling current period sales and profits.

2) Early recording of transactions, such as backdating a large sale so as to boost current year's profits.

3) Late recording of transactions, such as forwarddating a large sale so as to smooth revenues and profits between adjacent years, otherwise called income smoothing.

4) Misstating percentages or amounts involved in a transaction.

5) Misstating the amounts of assets or liabilities. An instance is where the value of impaired assets (nonperforming loans and obsolete inventory) are not written down in order to improve the reported profitability as well as the company's financial condition.

6) Changing accounting methods and policies on flimsy reasons.

7) The use of related party transactions to alter reported profits, as exemplified in transactions with an unconsolidated subsidiary at favourable prices to the parent company. This positions the parent company as making much profits during the period.

8) Recording of fictitious transactions or amounts in order to improve their reported profitability and financial condition.

9) Manipulation of company's research and development (R\&D) to generate high net operating assets 
returns as well as capital employed in future years when the $\mathrm{R} \& \mathrm{D}$ will be successful [6].

\section{B. Theoretical Framework}

The various literature written on earnings management anchor on the agency theory. This paper is not an exception. According to [8] agency relationship exists in the law of contract, since the principal (shareholders) hire the agents (management) with the authority to make economic decisions on their behalf towards maximizing their wealth in the companies. This assertion is similarly put up by [25] who noted that for the agents to be true to form, they must examine the risks in any decision taken so as to have the expected yield for the principal. This settles the agency theory.

[26] noted a problem which normally arise in the principal-agent relationship as short-termism, where managers go into short-term profits to satisfy their earnings rather than the long-term vision of the shareholders. This is one of the reasons for earnings management within the framework of agency theory.

\section{Empirical Framework}

[23] carried out a study on the role of accounting professionals in earnings management. He identified four common areas of potential abuse of financial reporting. The study adopted a desk review approach and it was revealed that accounting professionals and the financial reporting regulators have not done enough to protect the investing public.

[26] carried out a research on effect of earnings management on shareholders wealth maximization in Nigerian listed companies. The objective of that study was to find out if earnings per share and dividend per share could be influenced by earnings management. Econometrical analysis through panel regression was employed in the study and result showed that discretionary accrual which was used as the proxy for earnings management did not have any significant relationship with earnings or dividend per share. This was against the a priori expectation and it was recommended that management should strengthen the internal control and uphold corporate governance mechanism so as to reduce the unethical accounting practices that would not help in sustaining the shareholders wealth.

[16] in a study entitled "Earnings management research: A review of contemporary research methods" reviewed the various methods used in detecting earnings management in a firm. They criticized the use of accrual approach which is widely used as a variable in earning management studies, indicating that it has some shortcomings. Other methods as used in this study were used by the researchers and the limitation of discretionary accruals were highlighted and it was concluded that there is the need for use of estimation process which showed remarkable improvements empirically, as against discretionary accruals approach.

[22] empirically investigated the effect of financial information on investment decision making by shareholders of banks in Nigeria. The study extracted secondary data from published annual reports of five selected banks in Nigeria from 2009 to 2015. Correlation matrix and regression analysis were used to analyze the data and the findings showed a positive relationship between the variables of the study. This was in tandem with an earlier study by [5] on the effect of financial information on investment in shares. It was recommended that both existing and prospective investors can factor financial information relating to dividend per share, a proxy of financial information, while making investment decision in shares.

\section{METHODOLOGY}

This study adopted content analysis using the quantitative and qualitative approaches. The data were sourced from secondary sources, vide Nigerian Stock Exchange fact books, CBN bulletins and SEC website. Accounting professionals and staff of regulating agencies offered their sincere opinions when they were interviewed on the adherence to the generally accepted accounting principles (GAAP) by management of companies.

\section{DISCUSSION OF FINDINGS}

The expectation of every investor is to have adequate returns on the investment made. Most private and institutional investors have failed to use the services of professionals when they decide to make investment in listed companies. It is a fact that financial statements act as mirror reflecting the health status of the firm. Therefore, when juicy financial reports are published in the public domain, there exist the crave for investors to put their funds to become shareholders in the company. The existing shareholders are not left out, as they may wish to increase their investments, expecting a higher yield in the future.

However, the opinions and suggestions of the various professionals and key staff of regulatory agencies interviewed point to the facts discussed here, concerning the findings of this study:

Developing the capital market, prima facie, involves creating awareness on the stakeholders about the market as a catalyst for socio-economic advancement. The Security and Exchange commission (SEC) and other regulators in the capital market have the duty to showcase capital market development as involving research activities with the aim of improving market efficiency and competitiveness. The SEC, while doing this must work hard on its primary regulatory role of protecting the investing public from deceit and sharp practices which can destabilize the market.

This discussion focuses on the manipulation and falsification of financial statements by companies for their selfish interest. In the last decade, Nigeria had witnessed the fluctuation of the capital market by companies, mostly financial houses like banks who flooded the market with initial public offering (IPO) which turned out to have lower value than what was presented in the prospectus. Many investors were wooed by this strategy and got trapped when the companies failed with their investments. The capital market was destabilized.

This discussion highlighted some weaknesses on the major capital market regulators, such as the Security and Exchange commission (SEC) and the Nigerian Stock Exchange (NSE). Questions arose on how effective their regulatory role had been. How were the companies registered to exhibit their fitness or otherwise to do business 
in the capital market? Was the worthiness for the instrument for offer ascertained? As empowered by its enabling Acts, were the regulators apt to investigate all reports of violations or suspected violations of the market rules? How active has the enforcement been? Do the regulators review the accounts of companies on regular basis? Has the timing of issues in order to avoid unnecessary pressure on the market been carried out?

These questions and many more could be answered when the professionals who are at the helm of affairs in the various regulatory agencies take the ethical consideration of their profession seriously. This discussion highlighted the fact that when ethics are thrown overboard, adequate control and regulation would be absent and the financial reports would not be real, leaving the investors to woes.

The companies and allied matters Act, 1990 as amended must be seen to be complied with in all ramifications. In mergers and acquisitions, intensive work should be done to review every combination of companies and their books before consummation. Regulating agency like the Nigerian Stock Exchange must be seen to provide opportunity for continuous assessment of the value of listed securities as well as the worth of their issues. Quoted companies as provided by law must submit their detailed and periodic information which must be verified before such information is made available to the investing public.

The Central Bank of Nigeria, another regulator, in 2009 issued a blanket directive to stop margin investing in Nigeria. This development has helped in checkmating earnings management in this direction. Prior to this time, money was borrowed from brokers to buy equities and use such investment as collateral. In this discussion, it was analyzed that the Central Bank's action was timely to stem the tide of earnings management as the margin trading impacted negative influence on equity prices of companies in Nigeria. At the last count investments were lost as banks were collapsing as a result of these acts.

Another dimension to this discussion is that the banks in Nigeria at that time did not have a uniform year-end. Prior to the uniform year-end directive by the $\mathrm{CBN}$, investors were swindled as a result of poor returns on investment arising from margin trading activities. Return on investment were in the region of $9 \%$ as against 18 to $20 \%$ interest charge on bank loans [7].

There are many implications inherent in earnings management practice. In the opinion of the experts, auditors and accountants have increase in professional risks. Auditors have the expectation gap concept to grapple with, as members of the public expect them to know all and it is expected that they could detect all errors and frauds in the financial statements of companies they have audited.

\section{CONCLUSION AND RECOMMENDATIONS}

Financial reports are the mirror which reflects the true position of the company. If the report is concomitance with earnings management strategies, the true reflection of the company will be absent and the investing public will meet with adverse returns to their expectation. To avoid this, all regulators in the capital market must live up to their responsibilities regarding their operations laws. Professional accountants and auditors must be seen to exhibit ethical practices in the discharge of their assignments. Earnings management should be seen as a corruptive tendency which if allowed to thrive, the value of listed companies would be eroded in the long term and the wealth of shareholders would be minimized rather than maximized.

It is recommended that provisions of the International Financial Reporting Standards (IFRS) on financial reports as enshrined in IAS 1 and other generally accepted accounting principles (GAAP) be adhered to, strictly.

The services of professional accountants should be sought by every potential investor for advice, and the Financial Reporting Council of Nigeria (FRCN), SEC and indeed all regulators of financial reporting should be up and doing in their oversight functions. This will help in giving direction to the investing public and strengthen the confidence of the investors.

\section{ACKNOWLEDGMENT}

The researchers sincerely recognize and thank all individuals, too many to say publicly, who have contributed directly or indirectly towards the achievement recorded during the preparation of this manuscript, most especially management and staff of the selected quoted companies, the Federal Office of Statistics, Nigeria, the Central Bank of Nigeria, Security and Exchange Commission, Investments and business analysts and the Nigerian Stock Exchange.

\section{REFERENCES}

[1] A. Sullivan and S. M. Sheffrin. Economics: Principles in action, New Jersey: Pearson Prentice Hall, 2003

[2] A. E. Osuala, E. C. Ugwuma and I. J. Osuji (2012). Financial statements content and investment decisions- A study of selected firms. Journal of Research in National Development (JORIND). 10(2). pp. $165-170$.

[3] A. O. Okolie (2006). Corporate profitability and earnings quality management. ICAN Students Journal. 10 (4). pp. 12-17.

[4] A. P. Sweeny (1994). Debt covenant violations and managers accounting responses. Journal of Accounting and Economics. 17(1). pp. $281-308$.

[5] B. Gentry and I. O. Fernandez (2008). The effect of financial information on investment in shares. International Journal of Business and Commerce. 3(8). pp. 32-46.

[6] B. Yadav (2014). Creative accounting: An empirical study from professional prospective. International Journal of Management and Social Sciences Research (IJMSSR), 3(1), 38-53.

[7] C. B. N. Exposure draft CODE for banks in Nigeria. Abuja: Central Bank of Nigeria, 2012

[8] C. W. Mulford and E. E. Comiskey. Financial numbers game: Detecting creative accounting practices. Georgia: John Wiley and Sons, 2009.

[9] D. Vickrey and C. Bettis (2000). The incremental information content of operating cash flows and accruals. Journal of Accounting and finance. 8(2). pp. 27-36.

[10] G. P. Wilson (1986). The relative information content of accruals and cash flows. Journal of Accounting research. 241). pp. 165-200.

[11] G. Richardson, R. Lanis and G. Taylor (2015). Financial distress, outside directors and corporate tax aggressiveness spanning the global financial crises: An empirical analysis. Journal ofBanking and Finance. 52(1). pp. 112-129.

[12] H. Stolowy and G. Breton (2004). Accounts manipulation: A literature review and proposal. Review of Accounting and Finance. 1(5). pp. 55-66

[13] I. M. Zakari (2017). Non compliance to laws and regulations. The Nigerian Accountant Journal of ICAN. 50(3). pp. 4-5. 
[14] J. L. Smith. Accounting principles. New York: McGraw Hill Co, 2006.

[15] K. A. Merchant and J. Rockness (1994). The ethics of managing earnings: An empirical investigation. Journal of Accounting and Public policy. 13 (1). pp. 79-94.

[16] L. Sun and S. Rath (2010). Earnings management research: A review of contemporary research methods. Global Review of Accounting and Finance. 1(1). pp. 121-135.

[17] M. A. Trombey. Accounting for derivatives and Hedging. New York: Mcgraw Hill/Irwin, 2003.

[18] M. a. Desai, D. Dharmapala (2009). Corporate tax avoidance and high-powered incentives. Journal of Financial Economics. 79(1). pp. 145-179.

[19] M. Hanlon and J. Slemlod (2009). What does tax aggressiveness signal? Evidence from stock price reactions to news about tax shelter involvement. Journal of Public economics. 93(1,2). pp. 126-141.

[20] O. A. Johnson (2015). IPAS adoption in Nigeria: A subtle transformation tool. The Nigerian Accountant journal of ICAN. 48(2). pp. 47-49.

[21] O. J. Ilaboya. Modern practice of banking. Lagos: Rehiz Printers and publishers, 2005

[22] P. I. Zayol, T. Agaregh and B. Eneji (2017). Effect of financial information on investment decision making by shareholders of Banks in Nigeria. IOSR Journal of Economics and Finance. 8(3). pp. 20-31.

[23] P. J. Carruth (2002). Earnings management: the role of accounting professionals. International Business and Economics research Journal. 1(3). Available: https://doi.org/10.19030/iber.vii3.3899.

[24] S. B. Livingstone (2007). Effective finance. New York: McGraw Hill, 2007.

[25] S. H. Penman. Financial statements analysis and security valuation. New York: McGraw Hill, 2007.

[26] W. A. Sanyaolu (2017). Effects of earnings management on shareholders' wealth maximization: evidence from Nigerian listed firms. International Journal of Management Sciences and Business Research. 6(4).pp. 67-74.

\section{AUTHORS’ PROFILES}

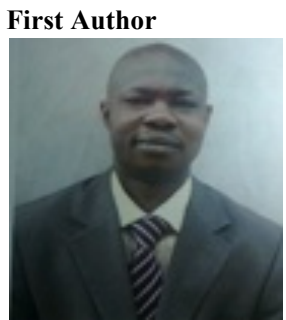

Dr. Uwem E. Uwah is a Chartered Accountant He holds B.Sc., M.Sc., MBA and Ph.D degrees in Accounting. His core competence areas are Cost and management accounting, Strategic financial management/Corporate finance, Public sector accounting and finance, and Management information system.

$\mathrm{He}$ is a fellow of the Institutes of Chartered Accountants of Nigeria, and Corporate Administration of Nigeria. Dr. Uwah has several academic papers to his credit, and currently lectures at the Akwa Ibom State University, Obio Akpa Campus, Nigeria.

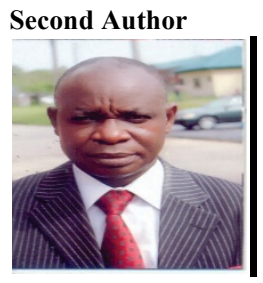
PhD degrees in Accounting. He has professional certificates: FCNA FCCA and FIIA. He is a member of many professional bodies at home and abroad; and a committed community development leader. Professor Udoayang has attended many local and international conferences and had presented cutting edge research papers in all these conferences. 